\title{
Colgajo submental para reconstrucción de defectos oncológicos en cabeza y cuello
}

\author{
Submental flap to reconstruct oncologic head and neck defects
}

\author{
J. Brunsó Casellas', J.C. Martín Rodríguez², L. Barbier Herrero², E. Ortiz de Zárate Román², \\ A. Bidaguren Urbieta ${ }^{1}$, J. Santamaría Zuazua ${ }^{3}$
}

\begin{abstract}
Resumen: El colgajo submental es un procedimiento eficaz para la reconstrucción en el territorio maxilofacial. Caracterizado por su delgadez, versatilidad, excelente color y textura y mínima morbilidad en la zona donante, su utilización en lesiones malignas es controvertida, por el riesgo de trasladar enfermedad metastásica cervical a la zona receptora. Material y métodos: Se presentan 3 casos clínicos en los que se ha aplicado en pacientes afectos de un carcinoma epidermoide de cabeza y cuello. Describimos las particularidades anatómicas, y se realiza una revisión de la técnica quirúrgica. Resultados: Fueron óptimos en cuanto a cobertura del defecto, estética y función salvo por una necrosis parcial en uno de ellos. En todos los casos la morbilidad en la zona donante fue mínima. Conclusiones: El colgajo submental es una opción a considerar incluso en pacientes oncológicos sobre todo en los que, por edad avanzada o presentar patología asociada no están indicados procedimientos más agresivos.
\end{abstract}

Palabras clave: Colgajo Submental; Reconstrucción cabeza y cuello; defectos orales y maxilofaciales.

Recibido: 01.09.2008

Aceptado: 11.05 .2009
Abstract: The submental flap is an effective option for the reconstruction in the maxillofacial territory. Characterized by its thinness, versatility, excellent colour and texture and minimum morbidity in the donor zone, its use in malignant injuries is controverted by the risk of transferring cervical metastasic disease to the receiving zone. Material and methods: we present 3 clinical cases in which it has been used in patients affected by an squamous cell carcinoma of head and neck. In addition, the anatomical particularities are described, and a revision of the surgical technique is made. Results: They were optimal in relation to covering of the defect, aesthetics and function except for a partial necrosis in one of them. In all the cases the morbidity in the donor zone was minimum. Conclusions: The submental flap is an option to consider in oncologic patients, mainly in those whom by advanced age or by the existence of comorbidity advice against the use of more aggressive procedures.

Key words: Submental flap; Head and neck reconstruction; Oral and maxillofacial defects.

\footnotetext{
1 Médico residente

2 Médico adjunto

3 Jefe de servicio

Servicio de Cirugía Oral y Maxilofacial. Hospital de Cruces. Barakaldo, España
}

\section{Correspondencia:}

Joan Brunsó Casellas

C/ Larrinaga, $\mathrm{n}^{\circ}{ }^{1}$. $2^{\circ}$ interior izquierda

48003 Bilbao. Vizcaya, España

Email: jbrunso@gmail.com 


\section{Introducción}

La extirpación de lesiones de gran tamaño en el territorio maxilofacial implica la necesidad de reconstrucción. En los defectos importantes los colgajos libres microvascularizados serían de elección. Colgajos delgados y versátiles como los fasciocutáneos radial y ALT han demostrado sobrada eficacia. Estos ofrecen indudables ventajas, pero también inconvenientes, como tiempos quirúrgicos prolongados, morbilidad en la zona donante, problemas estéticos, y un mayor riesgo de fracaso. A pesar de no existir contraindicaciones absolutas, estos no estarían indicados en pacientes de alto riesgo quirúrgico ya sea por severa comorbilidad o por edad avanzada. En estos casos se opta por el uso de colgajos pediculados o por tratamientos alternativos como la radioterapia o la quimioterapia.

El colgajo submental (CS) es un colgajo axial descrito por Martin et al. ${ }^{1}$ en 1993 tras aplicarse con éxito en 8 pacientes. Durante este tiempo las indicaciones para lesiones de tamaño medio en el territorio maxilofacial han sido ampliamente descritas. Se caracteriza por su delgadez, versatilidad, mimetismo con la piel facial y una mínima morbilidad en la zona donante. No obstante, su uso en lesiones malignas es controvertida por el riesgo de trasladar enfermedad metastásica regional del cuello a la zona receptora.

Presentamos 3 casos clínicos en los que se ha utilizado el colgajo submental en pacientes afectos de un carcinoma epidermoide del territorio maxilofacial, además de un repaso de la anatomía y de la técnica quirúrgica.

\section{Anatomía}

La arteria submental (AS) es una rama de la arteria facial. Nace en profundidad a la glándula submaxilar y transcurre a lo largo del borde inferior del cuerpo mandibular, por encima del músculo milohioideo hasta la sínfisis. Tiene un diámetro de entre 1 a 1,5 mm con un pedículo de unos $8 \mathrm{~cm}$. Circula por debajo del vientre anterior del músculo digástrico, donde emite la mayoría de perforantes cutáneas, aunque también puede pasar superficialmente.2,3 El número de perforantes varia de 1 a 4.2,4 También emite ramas para el periostio del hueso mandibular, los músculo milohioideo y platisma, y a nivel de la sínfisis mandibular, ramas para el labio inferior y la glándula sublingual.3,5 La AS termina contactando a través del plexo subdérmico con la rama contralateral permitiendo su extensión como colgajo random en el hemicuello contralateral. Esto permite levantar un colgajo grande de ángulo a ángulo mandibular. El drenaje venoso depende de la vena submental, que circula acompañando a la arteria submental para acabar drenando a la vena facial (Fig. 1).

\section{Técnica quirúrgica}

Con el paciente en posición de hiperextensión se dibuja el límite superior del colgajo justo por debajo del arco mandibular para disimular la cicatriz. La longitud de la paleta cutánea se puede pro-

\section{Introducción}

Removing large lesions from the maxillofacial zone involves the need for reconstruction. In serious defects free microvascularized flaps would be the choice. Thin and versatile flaps like the radial fasciocutaneaous and ALT have proven to be more than effective. They offer indubitable advantages, but also inconveniences for example: prolonged surgery time, morbidity in donor zone, aesthetic problems, and a high failure rate. Despite not having absolute contradictions these flaps would not be used on high risk surgery patients, whether it's because of comorbidity or old age. In these cases we opt to use pedicle flaps or alternative treatments like radio or chemo therapy.

The Submental Flap is an axial flap described by Martin et al.' in 1993 after successfully using it on 8 patients. During that time the indications for medium size lesions in the maxillofacial region had been thoroughly described. They were characterized by their thinness, versatility, mimicry with facial skin and minimal morbidity in the donor zone. Nevertheless, their use in malign lesions is controversial because of the risk of infecting the receiving neck area with cervical metastasic disease.

We present 3 clinical cases in which we used a submental flap on patients affected by squamous cell carcinoma of the maxillofacial region and we also review of anatomy and surgical technique.

\section{Anatomy}

The submental artery is a branch of the facial artery. It starts deep in the sub maxilla gland and continues along the inferior border of the mandible body, above the mylohyoid muscle until the symphysis. Its diameter measures 1.0-1.5 $\mathrm{mm}$ with a pedicle measuring $8 \mathrm{~cm}$. It circulates under the anterior abdomen muscle where the majority of perforating skin are emitted, although it can go over the surface. ${ }^{2,3}$ The number of perforates varies from 1-4.,2, It also emits branches for the periosteum of the mandible bone, the mylohyoid latissimus colli muscle, and even with the mandible symphysis, inferior lip branch and the sublingual gland. 3,5 Through the sub dermis plexus the submental artery ends up contacting the contra lateral branch allowing its extension as a random flap in the contra lateral neck. This allows the a large angle flap to be raised to the mandible angle. The vein drainage depends on the submental vain that circulates along with the submental artery and then ends up draining into the facial vein (Fig. 1).

\section{Surgical Technique}

With the patient in a hyper extended position we draw the superior limit of the flap just below the mandible arch in order to disguise the scar. The length of the cutaneous palette can extend from one mandible angle to the other. The infe- 
longar hasta los dos ángulos mandibulares. El límite inferior se dibujará después de comprobar el cierre directo con la prueba del pellizco. Se incide la paleta cutánea dividiendo la piel y tejido subcutáneo hasta el músculo platisma y se empieza a levantar el colgajo subplatismalmente de distal a proximal hasta exponer el músculo digástrico y la glándula submaxilar (Fig. 2). Seguidamente se separa la glándula submaxilar ipsilateral del colgajo ligando los vasos que se dirigen hacia ella. El siguiente paso es abordar el polo superior del colgajo dividiendo el músculo platisma e identificando la rama marginal del nervio facial y la arteria facial. Esta última se diseca cuidadosamente proximalmente hasta que esta se pierde por debajo de la glándula. En este punto traccionando la glándula distalmente se identifica la arteria submental; no obstante, no es preciso disecar la arteria submental para que el colgajo alcance la mayoría de lechos receptores más habituales. Evidentemente esto dependerá de la cantidad de pedículo que se precise.

Seguidamente se levanta el lado contralateral por debajo del músculo platisma de lateral a medial manteniendo íntegros la arteria facial y el vientre anterior del músculo digástrico. A nivel de la línea media se incorpora al colgajo el vientre anterior del músculo digástrico ipsilateral, desinsertandolo de la sínfisis y seccionándolo a nivel de la polea. En caso contrario, se deberá localizar las perforantes y disecarlas. Patel et al. ${ }^{6}$ describen una variante que consiste en incorporar al colgajo el músculo milohioideo del lado ipsilateral junto con el vientre anterior del músculo digástrico. Así, el pedículo queda protegido y el procedimiento es mucho más sencillo y rápido, aunque aumenta el grosor del colgajo.

La arteria facial es tortuosa y suficientemente larga para permitir un buen arco de rotación. Si la longitud del pedículo es suficiente, la cirugía finaliza acabando de liberar toda la paleta. Si es insuficiente, ligando la arteria y la vena facial distalmente al origen de la AS se consigue aumentarlo unos $2 \mathrm{~cm}$. Sterne et al. ${ }^{7}$ utilizaron por primera vez un CS con un diseño de flujo inverso ligando la arteria facial proximalmente al origen de la AS, consiguiendo aumentar considerablemente el pedículo. Kim et al. ${ }^{4}$ también lo usaron con éxito pero con variaciones. Pistre et al. ${ }^{8}$ consideran que este diseño inverso solo se debe usar cuando el flujo normal no es posible, ya sea por pedículo corto o por lesión arterial, ya que implica un alto riesgo de lesión del nervio facial al disecar distalmente el pedículo.

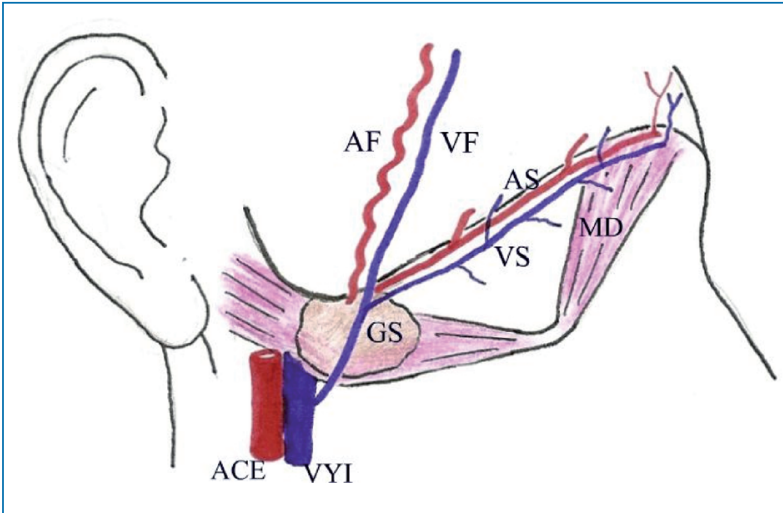

Figura 1. Dibujo esquemático de la anatomía. AF: arteria facial. VF: vena facial. ACE: arteria carótida externa. VYI: vena yugula submaxilar. MD: músculo digástrico.

Vein ECA. External Carotid Artery. IJV: Internal Jugular Vein. SA: Submental Artery. SV Submental Vein. SG: Sub maxilla gland. DM: Digastric Muscle.

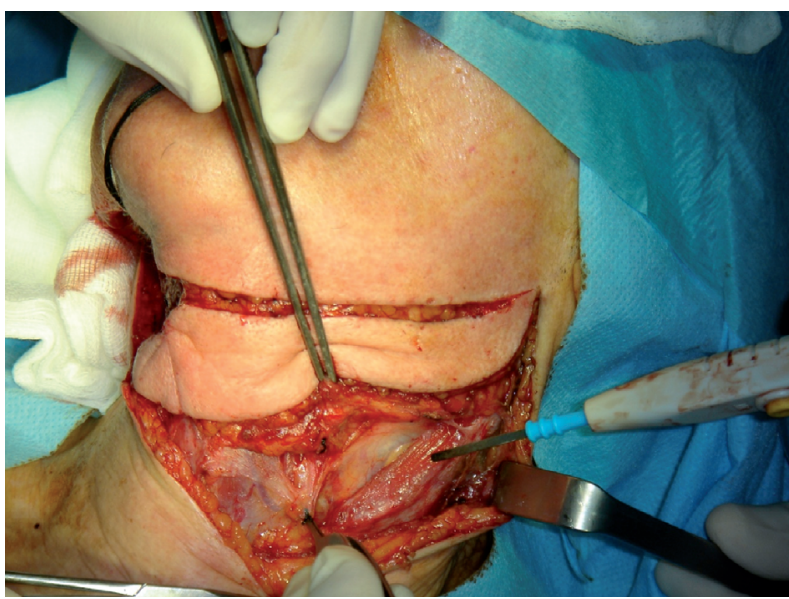

Figura 2. Incisión y levantamiento del colgajo subplatismalmente. Figure 2. Incision and raise of the subplatismally flap. rior limit is drawn after comparing the direct closing with the small sample. The cutaneous palette is divided by an incision that separates the skin and the subcutaneous tissue until the latissimus coli muscle and starts to subplatismally raise the flap from the distal until the digastric muscle and sub maxilla gland are exposed (Fig. 2) Shortly after the ipsilateral sub maxilla gland is separated from the flap attaching the vessels that come towards it. The next step is to approach the superior polo of the flap dividing the latissimus coli muscle and identifying the marginal branch of the facial nerve and artery. The facial artery is carefully dissected until it is lost under the gland. At this point traction of the gland identifying the submental artery; however, it is not necessary to dissect the submental artery so that the flap reaches the majority of the most habitual receptor layers. Obviously that depends on the quantity of pedicle needed.

Afterwards the contra lateral side is raised from underneath the latissimus coli muscle of lateral to medial maintaining the facial artery and anterior digastric abdominal muscle intact. Even with the mid line, the flap is inserted into the anterior abdomen of the ipsilateral digastric muscle, removing it from the symphysis and dividing it even with the polea. In the opposite case the perforants should be located and dissected. Patel et al. $\left.{ }^{6}\right)$ describe a variable that consists of incorporating the mylohyoid muscle on the ipsilateral side to the flap as well as the anterior abdomen of the digastric muscle. In this way the pedicle is protected and the procedure is much simpler and faster, although the thickness of the flap is increased.

The facial artery is tortuous and large enough to allow for good arch rotation. If the longitude of the pedicle is sufficient the surgery ends up freeing the whole palette. If it is insufficient, the artery and the facial vein are distally attached to the origin of the submental artery and it is increased by $2 \mathrm{~cm}$. Sterne et al. ${ }^{7}$ used CS for the first time with an inverse 
También podemos aumentar la longitud del pedículo venoso disecando una rama comunicante entre la vena facial y la yugula externa. Ligando la vena facial, la $Y$ vascular pasa a ser una $\checkmark$ vascular permitiendo ganar $5 \mathrm{~cm} .{ }^{9}$

La utilización de un colgajo submental no impide la realización de una disección cervical radical. No obstante esta obligará a modificaciones en el diseño de la incisión que dependerá del tamaño del colgajo y del lado pediculado. Es recomendable empezar primero levantando el colgajo para así proteger el pedículo. En colgajos grandes se amplía la incisión a nivel del extremo lateral de la elipse hasta la región mastoidea realizando una incisión vertical unos $2 \mathrm{~cm}$ por detrás del ángulo de la mandibula hasta la clavícula evitando ángulos agudos (Fig. 3). En colgajos pequeños es posible realizar un diseño de base superior que asegura una mejor irrigación. 6

Por último comentar que también se ha descrito como colgajo libre, $1,8,10$ y como colgajo compuesto incorporando hueso de la cara interna de la sínfisis mandibular; en cuyo caso debe estar asociado a una porción del músculo milohioideo. ${ }^{8,11}$

\section{Casos clínicos}

Caso 1: Varón de 80 años con una lesión T4 indurada, filiada como carcinoma epidermoide en la mitad anterior de lengua, vientre lingual y suelo de boca que provoca un desplazamiento de la lengua con dificultad para la dicción y la deglución. En las pruebas de imagen no se evidencia enfermedad metastásica a nivel regional y/o a distancia (T4NoMo). El paciente presenta un aceptable estado general que, si bien no contraindicaba una intervención más agresiva, por su edad y el pronóstico se optó por la opción menos radical: extirpación con márgenes, reconstrucción con CS y conducta expectante cervical. Se obtuvo un colgajo de 17x8. Como la paleta cutánea era excesiva desepitelizamos el extremo lateral ipsilateral hasta conseguir el tamaño adecuado a los limites del defecto a reconstruir (Fig. 4). Seguidamente se tunelizó el colgajo entre los músculos genihiodeos dividiendo el músculo milohioideo por la línea media. En el postoperatorio inmediato se observo congestión venosa del colgajo que empezó a remitir a los 4 días (Fig. 5). También apareció un hematoma cervical que se reabsorvió espontáneamente. El paciente presentó una evolución favorable siendo dado de alta a los 8 días y no presenta signos de enfermedad en la actualidad. El defecto resultante en la zona donante ha sido mínimo. flow design attaching the facial artery close to the origin of the submental artery, achieving considerable increase of the pedicle. Kim et al. ${ }^{4}$ also successfully used it but with variations. Pistre et al. ${ }^{8}$ thought the inverse design should only be used when the normal flow is not possible, either because the pedicle is too short or because of an artery injury, since there is a high risk of injuring the facial nerve when distally dissecting the pedicle.

We can also increase the length of the venous pedicle by dissecting a communicative branch between the facial vein and the external jugular. Attaching the facial vein, the $Y$ vascular becomes a $\mathrm{V}$ vascular allowing for a $5 \mathrm{~cm}$ gain. ${ }^{9}$

The use of the submental flap does not interfere with a radical cervical dissection. Nevertheless it makes it necessary to modify the incision design that depends on the size of the flap and the pedicle side. It is recommended to start by first raising the flap to protect the pedicle. With large flaps the incision is bigger from lateral extreme of the ellipse until the mastoid region, carrying out a vertical incision of $2 \mathrm{~cm}$ behind the mandible angle until the clavicle, all the while avoiding sharp angles (Fig. 3). For the small flaps it is possible to carry out a design with a superior base that ensures better irrigation. ${ }^{6}$

Finally we comment that the internal facial bone of the mandible symphysis has been described as a free flap and also a compound flap; In which case it should be associated to the portion of the mylohyoid muscle. ${ }^{8,11}$

\section{Clinical Cases}

Case 1: Male 80 years old with indurate T4 lesion, diagnosed as a squamous cell carcinoma of the anterior half of the tongue, the belly of the tongue and the floor of the mouth provokes the displacement of the tongue which makes diction and swallowing difficult. The image tests didn't show evidence of metastasic at the regional level nor at a distance (T4NOMO). The patients are in a generally acceptable state 
Caso 2: Mujer de 81 años que presenta un Carcinoma Epidermoide de encía mandibular del tercer cuadrante con infiltración de la musculatura del labio inferior (Fig. 6), sin evidencia de enfermedad metastásica a nivel cervical en la exploración física ni en el estudio con pruebas de imagen. Se decidió realizar la extirpación de la lesión de encía y labio con márgenes con mandibulectomía segmentaria, disección cervical supraomohioidea ipsilateral y reconstrucción con colgajo submental de pedículo contralateral y bucinador ipsilateral (Fig. 7). El postoperatorio presentó una evolución favorable. La paciente precisó un adelgazamiento del colgajo bucinador estando al año sin evidencia de enfermedad. La secuela en la zona donante ha sido mínima.

Caso 3: Mujer de 83 años que presenta recidiva de Carcinoma Epidermoide en suelo de boca, tras haber sido intervenida 10 meses atrás con extirpación, mandibulectomía, disección cervical supraomohioidea y reconstrucción con placa de osteosíntesis. La paciente no presenta enfermedad metastásica a nivel cervical ni a distancia en las pruebas de imagen. Se decide extirpación de la recidiva con márgenes y reconstrucción del defecto con un colgajo submental con pedículo contralateral. El colgajo se tunelizó a través del músculo milohioideo (Fig. 8). La paciente presentó en el postoperatorio necrosis de un tercio del CS en el extremo crítico; no obstante, este no requirió ningún otro proceso reconstructivo. En la actualidad la paciente presenta metástasis a distancia.

\section{Discusión}

Baudet et al. ${ }^{12}$ demostraron en su trabajo de 2003 que la mayoría de procesos reconstructivos en cabeza y cuello son satisfactoriamente resueltos con procedimientos quirúrgicos convencionales, indicando los colgajos libres microvacularizados para cuando los primeros no son suficientes. El CS ha demostrado su versatilidad en lesiones de la mitad inferior de la cara por traumas, tumores, quemaduras, 2,7,8,13,14 enfermedad del noma. 8,15 En la mejora del contorno facial en microsomias hemifaciales y parálisis faciales, ${ }^{16}$ para reconstruir el paladar, ${ }^{17}$ y para lesiones en suelo de boca. ${ }^{6,10,18,19} \mathrm{Kim}$ et al. ${ }^{4}$ utilizaron un CS de flujo inverso para reconstruir la nariz. Pistre et al. ${ }^{8}$ lo usaron como colgajo compuesto incorporando hueso that, even though aggressive intervention is not advised because of his age, the prognostic suggests a more radical option: excision with margins, reconstruction with CS and expectant cervical conduct. A $17 \times 8$ flap was obtained. Because the cutaneous palette was excessive we depithelize the ipsilateral lateral extreme until we achieved the adequate size at the limits of the defect to be reconstructed (Fig. 4). After this we tunneled the flap between the geniohyoideus muscles dividing the mylohyoid muscle along the mid line. In post op there was vein congestion in the flap that started to relax after 4 days (Fig. 5). A cervical bruise also appeared but reabsorbed spontaneously. The patient showed favorable progress and was discharged after 8 days and did not present signs of illness at that time. Defect of the donor zone was minimal.

Case 2: Female 81 years old with Squamous Cell Carcinoma of the 3rd quadrant mandible gum with infiltrated inferior labial muscles (Fig. 6). No evidence of metastatic disease at the cervical level during the physical exam and image tests. We decided to excise the lesion of gum and lip with mandibulectomy segmented margins, cervical supraomohyoid ipsilateral dissection and reconstruction of the submental flap of the contra lateral pedicle and ipsilateral buccinators (Fig. 7). In the post op she showed favorable progress. The patient specified a thinning of the buccinator flap and after one year showed no sign of disease. The after effect of the donor zone was minimal.

Case 3: Woman 83 years old with Squamous Cell Carcinoma on the buccal floor 10 months after having excision, mandibulectomy, supraomohyoid cervical dissection and reconstruction of the osteosynthetic plate. The patient did not show signs of cervical metastasic even at a distance in the image tests. We decided to excise the relapse with margins and reconstruct the defect with a submental flap with contra lateral pedicle. The flap was tunnelized via the mylo- 
mandibular. Kitazawa et al. ${ }^{20}$ utilizaron el colgajo bipediculado para reconstruir una lesión de labio superior. Por tanto, el CS puede ser una alternativa válida a los colgajos libres microvascularizados. $2,7,13,14,16,18,19$ Otros colgajos regionales como el platismal, ${ }^{21}$ supraclavicular, ${ }^{22}$ infrahioideo, ${ }^{23}$ y colgajos locales tipo random pueden tener características parecidas pero generalmente ofrecen menor movilidad, menor fiabilidad, mayor secuela en zona donante y paletas cutáneas de menor tamaño. Pistre et al. ${ }^{8}$ acaban considerando el CS como el mejor método reconstructivo para defectos faciales tras aplicarlo con éxito en 31 pacientes.

En casos oncológicos, algunos autores consideran una contraindicaciones absoluta para su uso la presencia de enfermedad metastásica manifiesta en nivel I. ${ }^{1}$ Nosotros pensamos que en los casos en los que hay ganglios positivos cervicales sería conveniente valorar otras opciones reconstructivas, ya que, como Shah et al. ${ }^{24}$ demostraron en 1990, la incidencia de ganglios positivos en el nivel I después de una disección electiva es del $20 \%$, comparado con el $48 \%$ después de una disección terapéutica en el carcinoma epidermoide de cavidad oral. Estaría indicado, por tanto, para casos oncológicos sin enfermedad metastásica cervical y también para pacientes que por edad o severa comorbididad no sean candidatos a procedimientos más agresivos; incluyendo entre estos, casos de cirugía paliativa. No obstante, es conveniente valorar cada caso en particular y en los pacientes que precisen de una linfadenectomía cervical será condición imprescindible la realización de una meticulosa técnica quirúrgica para minimizar riesgos.

Los resultados por nosotros obtenidos coinciden con los descritos en la bibliografía. El CS consiguió cubrir los defectos de forma satisfactoria. En ninguno de los casos hubo fallo completo del colgajo pero si necrosis parcial de la zona critica del colgajo en el tercero, posiblemente por la tunelización que se realizó para alcanzar mejor la zona a reconstruir. El colgajo también demostró una alta tolerancia a la radiación no existiendo complicaciones tras el tratamiento radioterápico complementario. Tampoco ha habido indicios de traslado de enfermedad cervical a la zona receptora, manteniéndose el lecho receptor libre de enfermedad. No obstante, el paciente del caso 3, presenta enfermedad metastásica a distancia a los 7 meses de la intervención. En cuanto al tamaño

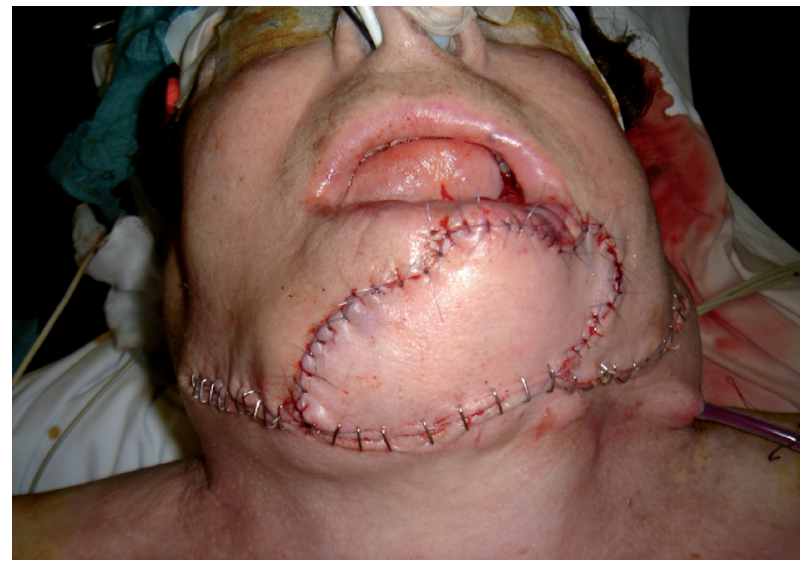

Figura 7. Fotografía postoperatoria del caso 2.

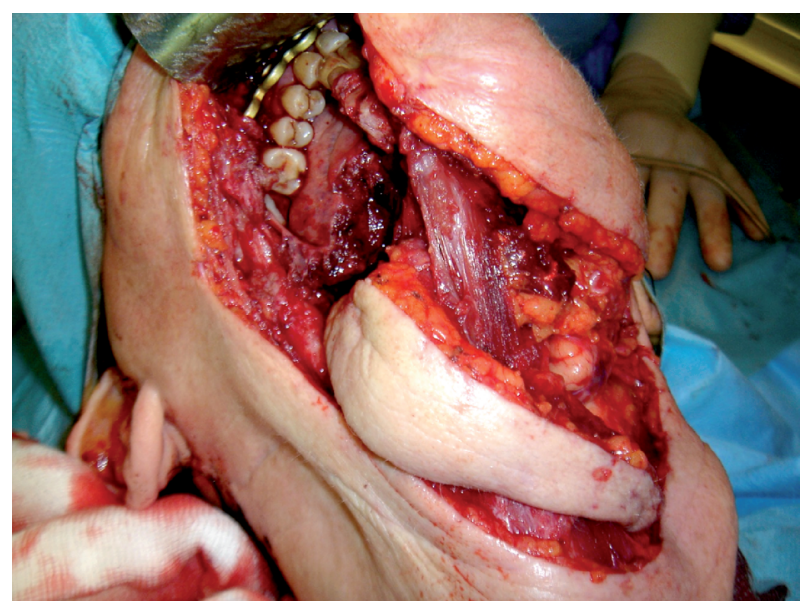

Figura 8. Fotografía intraoperatoria del caso 3 donde se muestra el defecto a reconstruir y la tunelización que se realizó a través del músculo milohioideo para poder alcanzar mejor la zona a reconstruir.

8. Photograph during operation in case \#3 which shows a reconstructive defect and tunnelization that was carried out through the mylohyoid muscle to be able to improve the reconstructed area. hyoid muscle (Fig 8). In post op the patient showed critical necrosis in a third of the submental flap. Nevertheless this did not need any further reconstruction. At the time the patient showed no signs of remote metastasis.

\section{Discussion}

Baudet et al. ${ }^{12}$ showed in his 2003 work that the majority of reconstructive processes of the head and next were resolved with satisfaction by using conventional surgical procedures. This indicates that free microvascularized flaps for the first ones are not sufficient. The submental flap has shown is versatility in lesions of the inferior half of the case of trauma, tumors, burns, 2,7,8,13,14 and noma disease. 8,15 In order to improve the facial contour in hemi facial microsomia and facial paralysis (160, hard palate reconstruction and buccal floor lesions, 6, 10,18,19 Kim et al. ${ }^{4}$ used a submental flap of inversed flow to reconstruct the nose. Pistre et al. ${ }^{8}$ used it as a compound flap and incorporated mandible bone. Kitazawa et al. ${ }^{20}$ used the bipedicle flap to reconstruct a superior labial lesion. Therefore, the submental flap can be a valid alternative to free microvascularized flaps. 2,7,13,14,16,18,19 Other regional flaps like the platismal, ${ }^{21}$ supraclavicular, ${ }^{22}$ infrahyoid, ${ }^{23}$ and random type local flaps can have similar characteristics but generally offer less mobility, less reliability, increased consequences in the donor zone and cutaneous palettes smaller in size. After using it on 31 patients, Pistre et al. ${ }^{8}$ considered the submental flap as the best method to reconstruct facial defects.

In oncology cases, some authors do not recommend its use when there is level I metastatic disease. We think that in cases where there are positive cervical ganglion it would be convenient to evaluate other reconstructive options since, like Shah et al. ${ }^{24}$ showed in 1990, the incidence of positive ganglions in the first level after elective dissection is $20 \%$ 
de la paleta, si bien Martin et al. ${ }^{1}$ recomendaba un tamaño máximo de $15 \times 7$ en nuestro caso 1 se obtuvo una paleta de 17 por 8 $\mathrm{cm}$, debido a la laxitud de la piel cervical del paciente. En todos los casos se optó por incorporar el vientre anterior del músculo digástrico para asegurar la perfusión y el drenaje del colgajo. Ninguno de los casos precisó de técnicas para aumentar la longitud del pedículo. En cuanto a lesión de la rama marginal del nervio facial, esta solo apareció en el caso 2 tras su extirpación por indicación oncológica; por lo general es baja en la mayoría de series aunque, en otras esta complicación llega a ser del 16\%.7

En la cavidad oral se consiguió preservar notablemente las funciones orales de alimentación y dicción. El pedículo es suficientemente largo para que este alcance casi la totalidad de la cavidad oral, consiguiendo reconstruir lesiones de lengua y suelo de boca incluso en pacientes déntulos. En los casos donde el CS debe ser tunelizado a través de la musculatura del suelo de la boca suele aparecer, en la mayoría de las series, congestión venosa que no suele comprometer la viabilidad del colgajo. En nuestro caso 1 esta se resolvió a los pocos días.

\section{Conclusiones}

El Colgajo Submental es una opción reconstructiva a tener en cuenta en pacientes oncológicos de cabeza y cuello que precisen de colgajos de tamaño considerable. Especialmente indicado para aquellos pacientes que por edad o enfermedad asociada requieran tratamientos poco agresivos y con tiempos quirúrgico reducidos, siendo una buena alternativa a los colgajos microvascularizados.

\section{Bibliografía}

1. Martin D, Pascal JF, Baudet J, Mondie JM, Farhat JB, Athoum A, et al. The submental island flap: A new donor site. Anatomy and clinical applications as a free or pedicled flap. Plast Reconst Surg 1993;92:867-73.

2. Curran AJ., Neligan P, Gullane PJ. Submental artery island flap. Laringoscope 1997;107:1545-9.

3. Martin D, Baudet J, Mondie J, Peri G. The submental island skin flap: A surgical protocol. Prospects of use. Ann Chir Plast Esthet 1990; 35:480-4.

4. Kim JT, Kim SK, Koshima I, Moriguchi T. An anatomic study and clinical applications of the reversed submental perforator-based island flap. Plast Reconst Surg 2002; 109:2204-10.

5. Whetzel TP, Mathers SJ. Arterial anatomy of the face: An analysis of vascular territories and perforating cutaneous vessels. Plast Reconst Surg 1992;89:591603.

6. Patel U, Bayles SW, Hayden R. The submental flap: A modified technique for resident training. Laryngoscope 2007; 117:186-9.

7. Sterne GD, Januszkiewicz JS, Hall PN, Bardley AF. The submental island flap. $\mathrm{Br}$ J Plast Reconst Surg 1996;49:85-9.

8. Pistre V, Pellissier P, Martin D, Lim A. Baudet J. Ten years of experience with the submental flap. Plast Reconst Surg 2001;108:1576-81.

9. Martin D, Legaillard P, Bakhach J, Hu W, Baudet J. L' allongement pediculaire en $\mathrm{YV}$ a flux retrograde: un moyen pour doubler I 'arc de rotation d'un lambeau sous certaines conditions. Ann Chir Plast Esthet 1994;39:403-14. compared to $48 \%$ after a therapeutic dissection of squamous cell carcinoma of the oral cavity. It would be suggested, therefore, for oncology cases that show no cervical metastatic carcinoma and also for patients that because of their age of serious comorbidity are not candidates for more aggressive procedures. Included in these would be cases of palliative surgery. Nevertheless it is convenient to evaluate each case in particular and the patients that specify cervical lymphadenectomy would definitely need a meticulous surgical technique in order to minimize risks.

The results we obtained coincide with those described in the bibliography. The submental flap satisfactorily covered the defects. None of the cases had a failed flap but some had partial necrosis in the critical third zone upon reconstruction, possibly because of the tunnelization that took place in order to improve the reconstruction zone. The flap also showed a high tolerance to radiation and there were no complications after complimentary radiotherapy treatment. There also were no indicators of having transferred the disease from the cervical receptor zone, maintaining the receptor layer free from disease. Nevertheless, the patient in case 3 showed metastasic 7 months after intervention. In terms of the size of the palette, even though Martin et al. ${ }^{1}$ recommended a maximum size of $15 \times 7$, in our case \#1 we had a palette measuring $17 \times 8 \mathrm{~cm}$ due to the laxity of the cervical skin of the patient. In all of the cases we chose to incorporate the anterior belly of the digastric muscle to assure perfusion and flap drainage. None of the cases specified techniques to increase the length of the pedicle. In terms of the lesion of the marginal branch of the facial nerve, it only appeared in case 2 after excision because of oncological indication; in general it is low in the majority of cases even though in others the complication occurs in up to $16 \%$.

The oral cavity managed to notably preserve its oral functions of feeding and expression. The pedicle is long enough so that it reaches the entire oral cavity, allowing the lesions to be reconstructed on the tongue and buccal floor including dental patients. In the case where the submental flap should be tunnelized through the muscular floor of the mouth in the majority of cases, venous congestion appears that usually does not risk the viability of the flap. In our case \#1 it was resolved in a few days.

\section{Conclusions}

The submental flat is a reconstructive option that should be considered when dealing with head and neck oncology patients that need a decent size flap. This flap is especially useful in elderly patients or patients that have other diseases that require them to have less invasive surgical treatments. This flap is a good alternative to the microvascularized flaps. 
10. Pistre D, Pelissier P, Martin D, Baudet J. The submental flap: Its uses as a pedicled or free flap for facial reconstruction. Clin Plast Surg 2001;28:303-9.

11. Yilmaz M, Menderes A, Barutcu A. Submental artery island flap for reconstruction of the lower and mid face. Ann Plast Surg 1997;39:305.

12. Baudet J, Casoli V, Pinsolle R, Tessier R, Pelissier P, Martin D. Conventional surgery in head and neck reconstruction. Is it out of date? ANZ J of Surg 2003;73:196.

13. Abouchadi A, Capot-Degardin N, Patenotre P, Martinot-Duquennoy $V$, Pellerin P. The submental flap in facial reconstruction: Advantatges and limitations. J Oral Maxillofac Surg 2007;65:863-9.

14. Demir Z, Kurtay A, Sahin U, Velidedeoglu H, Celebioglu S. Hair-bearing submental artery island flap for reconstruction of mustache and beard. Plast Reconstr Surg 2003;112:423-429.

15. Barthelemy I, Martin D, Sannajust JP, Marck K, Pistre V, Mondié JM. Prefabricated superficial temporal fascia flap combined with a submental flap in noma surgery. Plast Reconstruct Surg 2002;109:941-2.

16. Tan Onder, Atik Bekir, Parmaksizoglu Duygu. Soft-tissue augmentation of the middle and lower face using the deepithelialized submental flap. Plast Reconstruct Surg 2007;119: 873-9.
17. Genden EM, Buchbinder D, Urken ML. The submental island flap for palatal reconstruction: A novel technique. J Oral Maxillofac Surg 2004; 62:387-90.

18. Chow TL, Chan TT, Chow TK, Fung SC, Lam SH. Reconstruction with submental flap for aggressive orofacial cancer. Plast Reconstruct Surg 2007;120:431-6.

19. Merten SL, Jiang RP, Caminer D. The submental artery island flap for heard and neck Reconstruction. ANZ J of Surg 2002; 72: 121-124.

20. Kitazawa T, Harashina T, Taira H, Takamatsu A. Bipedicled submental island flap for upper lip reconstruction. Ann Plast Surg 1990; 42:83-6.

21. Hurwitz DJ, Rabson JA, Futrell JW. The anatomic basis for the platysma skin flap. Plast Reconst Surg 1983;72:302-14.

22. Hartman EH, Van Damme PA, Sauter H, Suominen SH. The use of the pedicled supraclavicular flap in noma reconstructive surgery. J Plast Reconstr Aesthet Surg 2006;59:337-42.

23. Wang $H$, Shen JW, Ma DB, Wang JD, Tian AL. The infrahyoid myocutaneous flap for reconstruction after resection of head and neck cancer. Cancer 1983;57:663.

24. Shah JP, Candela FC, Poddar AK. The patterns of cervical lymph node metastases from squamous carcinoma of the oral cavity. Cancer 1990; 66:109-13. 